\title{
HarvardX's Early Christianity: The Letters of Paul: a Retrospective on Online Teaching and Learning
}

\author{
Jennifer Aileen Quigley and Laura Salah Nasrallah
}

The edX/HarvardX course Early Christianity:The Letters of Paul was developed in 2013 and launched in 2014. While at the time such an open-access online course in biblical studies was a relatively new phenomenon, it was concurrent with educational sites that require payment, such as The Great Courses. ${ }^{1}$ Since the course, many other opportunities have emerged for free, open, and online scholarly study of ancient Christianity, the religion of antiquity, or Bible, such as Gary Anderson and John Cavadini's Jesus in Scripture and Tradition, ${ }^{2}$ Barry Scott Wimpfheimer's Coursera course The Talmud: A Methodological Introduction, ${ }^{3}$ Harvard's World Religions Through Their Scriptures, ${ }^{4}$ which is organized by Diane Moore and includes scholars presenting the global impact and interpretation of a variety of scriptures, or the more exploratory and encyclopedia style Bible Odyssey from the Society of Biblical Literature. ${ }^{5}$

Our chapter takes up the theme of digital academic communication and publication by discussing the development and launch of the online edX/ HarvardX course, Early Christianity: The Letters of Paul. This chapter offers a

$1<$ http://www.thegreatcourses.com/>, accessed on 10.04.19. The Great Courses is a subscription based service where students purchase access to individual courses. These courses are not live and interactive, but they do include lecture videos and other materials. Most courses, including offerings related to biblical studies, cost between $\$ 130-\$ 225$ per course.

$2<$ https://www.edx.org/course/jesus-scripture-tradition-notredamex-th120-1X>, accessed on 10.04.19.

$3<$ https://www.coursera.org/learn/the-talmud>, accessed on 10.04.19.

4 <https://www.edx.org/xseries/world-religions-through-scriptures $>$, accessed on 10.04.19. ScripturesX is a broad overview course, with 4 weeks dedicated to each of several major world religions' scriptural traditions, including Judaism and Christianity.

5 <https://www.bibleodyssey.org/>, accessed on 10.04.19. All of these courses are offered by scholars in the field of religion, theology, or biblical studies. The faculty for the Great Courses Bible courses include David Brakke, Cynthia R. Chapman, Bart Ehrman, and Luke Timothy Johnson. With the exception of pay-series such as the Great Courses, the proliferation of the courses mentioned above all have launched within the past three years, following the completion of Early Christianity: The Letters of Paul. 
history of our project, quantitative data about registrants and those who received certificates, and qualitative data about the experience of the teaching staff and online students. Moreover, this chapter considers the centrality of pedagogical considerations to our project, reflecting upon our experiment in whether and how feminist pedagogies could be deployed in a Mooc.

Given the growth of online education in biblical studies and its relative newness, a broader conversation about its role in our field is needed. ${ }^{6}$ Our chapter contends that this growth among organizations that can create and sustain Moocs (Massive Open Online Courses) should keep as a key goal the crafting of a public, free, and critical space for students who express a desire, no matter their location on the globe, to learn about and to discuss the Bible. As one step toward this broader conversation, this chapter lays bare a key if publicly unexpressed learning goal of our course: to foster an online location for the development of peaceful conversation and critical knowledge in the face of both the violence and promise produced in the name of and because of religion.

\section{Course Origin, Goals, Construction, and Pedagogy}

In January 2013, an email from HarvardX to Harvard faculty invited ideas for an online massive, open course. This was at the time when faculty at San Jose State University were protesting their administration's decision to ask the faculty to pilot Professor Michael Sandel's HarvardX course, "JusticeX," which would functionally render their philosophy faculty as teaching support for an already existing course. ${ }^{7}$ This was also a time when many expressed concerns about Moocs as a phenomenon in the academy that threatened intellectual diversity, tenure track lines, and faculty jobs - the very things that most con-

6 For discussion of the potential of for-pay online education in the field of business, and a reflection on pedagogy and students' ability to teach each other, see "Education at a Crossroads" and discussion of the formulation and launch of H Bs by its chief organizer, Anand, Bharat, The Content Trap: A Strategist's Guide to Digital Change, New York: Random House, 2016, 299-344.

7 <http://archive.boston.com/bostonglobe/ideas/brainiac/2013/05/san_jose_state.html>, accessed on 10.04.19; <http:/www.chronicle.com/article/The-Document-an-Open-Letter/ 138937>, accessed on 10.04.19. See also Sandel's response, which indicates that he did not intend and did not want JusticeX to be used in such a way: <http://www.chronicle.com/ar ticle/Michael-Sandel-Responds/139021/>, accessed on 10.04.19. JusticeX is now archived on edX, although Sandel shares similar content through $<$ http://www.justiceharvard.org/ $>$, accessed on 10.04.19. 
cern those of us who train doctoral students and who wish to preserve the ongoing life of academic freedom and intellectual diversity.

Nonetheless, Laura Nasrallah made the decision to go forward with a course for several reasons. First, HarvardX provided some photography and video equipment for graduate students to use during a seminar course that included travel to archaeological sites in Greece and Turkey, thus allowing the capture of high quality images for use in publications, for Harvard's New Testament Archaeology project, and for various other courses, including the HarvardX course. Second, HarvardX provided some funding and training of doctoral students. It seemed that doctoral students would benefit from experience in the preparation and execution of an online course. Such experience could be helpful in the current job market, providing an opportunity to think through a broad range of pedagogical issues not confronted in the brick and mortar classrooms of Harvard. Third, the larger educational landscape in the U.S. and abroad is experimenting with blended and online learning. Theological schools in particular, recognizing that their students do not have the luxury of a threeyear residential Masters of Divinity program, increasingly utilize online courses. It was worthwhile for all teaching staff to understand better the benefits and consequences of online teaching. Finally, in early 2014, when the course was offered, there were few female faculty engaged in HarvardX (and edX more broadly) and few courses offered in the Humanities. Was it possible to create a space in emerging MOоc venues for the humanities and for the study of religion? Was it possible to create a humanities/study of religion MOoc while engaging some of the principles of feminist pedagogy, which emphasizes the importance of students' past knowledge and experience as helpful to the analysis of course materials, rather than something to set aside; the work of students and teachers as co-learners; the significance of sharing ideas and knowledge; and the goal of engaging course materials with an eye to attending to the voices of women and others who are marginalized in the historical record? M oocs have a global reach, on the one hand, and often a "star" professor, on the other. Could one instead engage the experiment of feminist pedagogy in a MOOC, hoping that the course could engage with a diverse audience who could bring their own ideas and knowledge to the classroom? The course was organized to form and showcase a community of knowledge - a community among the faculty organizer of the course, teaching staff, and invited speakers, and also among the teaching staff and students.

In preparation for these goals, and in light of concerns about higher education in the United States, the possible monetization of moocs, and pedagogy, graduate students at Harvard, including the six graduate students involved in Early Christianity: The Letters of Paul, met with the instructor for an informal 
mini-course in the ethics of online education. The group read blogs and online articles debating the value and danger of Moocs, as well as more programmatic essays such as "An Avalanche is Coming." In addition, the teaching staff read texts that addressed broader questions of pedagogy. ${ }^{9}$

The teaching staff developed the course for approximately six months, and it launched in January 2014 for a five-week iteration through the edX portal, in partnership with Rap Genius, and using Facebook as an additional portal into the online course. ${ }^{10}$ While edX has archived Early Christianity: The Letters of Paul, ${ }^{11}$ the course materials, including all course videos, are still available online at a stable website, ${ }^{12}$ including videos and time-maps that provide photographs of archaeological sites. We have not run the course again since. ${ }^{13}$

The Early Christianity: The Letters of Paul through HarvardX was a very simplified portion of an introductory course offered at Harvard for undergraduate, masters, and doctoral students. In sum, it adapted portions of roughly 2.5 weeks of the brick and mortar course, and paced these over 5 weeks online, with content launched three times per week.

8 Barber, Michael, Donnelly, Katelyn, Rizvi, Saad, An Avalanche is Coming: Higher Education and the revolution ahead, London: Institute for Public Policy Research, 2013, <http://www. avalancheiscoming.com/>, accessed on 10.04.19.

hooks, bell, Teaching to Transgress: Education as the Practice of Freedom, New York: Routledge, 1994; Schüssler Fiorenza, Elisabeth, Democratizing Biblical Studies: Toward an Emancipatory Educational Space, Louisville, KY: Westminster John Knox, 20o9; Martin, Dale, Pedagogy of the Bible: An Analysis and Proposal, Louisville, KY: Westminster John Knox, 2008.

10 Some students participating in the course in locations without access to high speed internet requested discussions and course materials to be posted on Facebook, so the course team made the decision not only to allow students to participate in discussions through Facebook, but also to take the course through Facebook. Videos, discussion questions, and knowledge checks were all posted to the course page on Facebook. Students still needed to $\log$ in to edX (or link to Rap Genius) to access the readings, and students working toward a certificate of completion needed to log in to edX to complete their self-assessment (more on this below), but otherwise, the Facebook page allowed students to access a more limited amount of materials. Rap Genius took on the responsibility and liability for hosting course readings on their platform.

<https://www.edx.org/course/early-christianity-letters-paul-harvardx-hds1544-1x>, accessed, accessed on 10.04.19. All of the course materials, including discussion boards, student interactions, and all materials available to registered students, are still available at this website. The teaching team was updating the course both before and during the course, with the last update from the teaching team dating to March 7, 2014. <http://div.hds.harvard.edu/lettersofpaul/>, accessed on 10.04.19.

13 At least two factors affected this decision. First, other Harvard Divinity School colleagues began preparing an overarching world scriptures course soon after the completion of Early Christianity: The Letters of Paul. Second, despite the intensive workload of creating, preparing, and running a моос, faculty are currently not offered standardized additional compensation, leave, or course relief for teaching Moocs. 
TABLE 10.1 Course components of Early Christianity: The Letters of Paul; (C)JENNIFER QUIGLEY AND LAURA NASRALLAH

\section{Course Component Description}

Readings

Short videos

Conversational videos

Bibliographies

Discussion questions

Knowledge Checks
Primary and secondary readings offered both on the course website and through the Genius platform, which offered interactive text annotation Brief lectures offered by Nasrallah to introduce the day's topic, themes, and important historical context to the day's readings

Long-form videos featuring Nasrallah interviewing scholars on particular topics or leading doctoral student discussions on a particular text Additional scholarly material to encourage student's further exploration

Open-ended, interactive questions posted on discussion threads on the course website to encourage student interaction

Content-based review questions posted on discussion threads on the course website to encourage student interaction

Each launch included combinations of six components as given in Table 10.1. Our teaching team of one faculty member and four doctoral students answered questions, stimulated discussion, and moderated discussion boards at all hours for five weeks in January-February of 2014. Student participation, especially at the beginning, overwhelmed both the website and the teaching staff, who were trying to respond to the crashing wave of student involvement, which sometimes blocked students from website use. ${ }^{14}$ It also won the apostle

14 Within a few hours of launch, a discussion thread for Day 1 asking students to introduce themselves to one another accumulated 640 responses. Letters of Paul Course Report, 9. Archived discussion threads can also be viewed on the course website. At course launch, HarvardX did not nest discussion threads, which led to long site load times with discussion threads involving hundreds of comments. By the end of the course, nesting had been added to the discussion threads. Work still continues on enhancing features of online discussions and commenting, functions crucial to humanities courses but less utilized in Moocs in other fields. 
Paul a comparison with Beyoncé in the title of an online article, "More Popular than Beyoncé: The Apostle Paul at Harvard."15

Early Christianity: The Letters of Paul experimented with creating a feminist pedagogical space online. ${ }^{16}$ The course was grounded in ideas from Elisabeth Schüssler Fiorenza's work, such as her Democratizing Biblical Studies. She argues that historical analyses of the context of the production of biblical texts should also speak to contemporary issues. Her work insists upon an ethics of interpretation that is attentive to how biblical texts are often deployed for injustice - to perpetuate racism, sexism, anti-immigrant attitudes, hatred of other religions, and homophobia. Schüssler Fiorenza, in part drawing on the work of Krister Stendahl, sees the work of bringing ivory tower biblical studies to communities that use and care about the Bible as a crucial "public health" issue. ${ }^{17}$ The course also attempted to embody online the pedagogy espoused in bell hook's Teaching to Transgress, with its roots in Freire's Pedagogy of the Oppressed. hooks, offering a black feminist perspective, sees education as essentially dialogical, with classrooms co-constituted by those usually called teachers and those usually called students, and as working toward liberative purposes. ${ }^{18}$ Education can be a practice of freedom if and where it teaches that anyone can learn and that anyone can contribute to the production of knowledge. ${ }^{19}$ Could a MOoc, despite of its size and global reach, become a space that

15 McGovern, Celeste, "More Popular than Beyoncé: The Apostle Paul at Harvard." 2 April 2014, <http://www.thechristians.com>, accessed on 10.04.19.

16 These experiments are happening in a variety of online communities, including the creation of Distributed Open Collaborative Courses, or Doccs. This movement, started by FemTechNet in 2013 began with a course called Dialogues on Feminism and Technology. The following is a description of Doccs from FemTechNet: "A MOоc (massive open online course) is typically organized and branded by a single (elite) institution. A DocC recognizes and is built on the understanding that expertise is distributed throughout a network, among participants situated in diverse institutional contexts, within diverse material, geographic, and national settings, and who embody and perform diverse identities (as teachers, as students, as media-makers, as activists, as trainers, as members of various publics, for example)." "Docc 2013: Dialogues on Feminism and Technology," FemTechNet Commons, <http://femtechnet.org/wp-content/uploads/2015/07/2013Fall_ Pitzer_Juhasz.pdf $>$, accessed on 10.04.19. Since this first course in the winter of 2013, there are now a dozen "Nodal Courses" that have taken place. For larger issues in feminist pedagogy and biblical studies, see the work of Schüssler Fiorenza, Elisabeth, 2009.

See helpful discussion and citations in Marchal, Joseph, "To What Ends? Biblical Studies and Critical Rhetorical Engagement(s) for a 'Safer' World," $s B L$ Forum n.p. Online: <http:// sbl-site.org/Article.aspx?ArticleID=550 $>$, accessed on 10.04.19.

hooks, bell, Teaching to Transgress 130. hooks of course offers many other important perspectives, including that of embodied knowledge, which were less immediately applicable to the Mooc setting. 
formed a "classroom" or community in which such learning and production of knowledge occurred? Ultimately, feminist pedagogy moves the classroom real or virtual toward a democratic forum in which all were producing as well as receiving knowledge, where all were gaining tools to adjudicate knowledge. ${ }^{20}$

These feminist pedagogical models were also enacted by organizing the course in such a way to decenter the faculty member who could be misunderstood as the sole star or "owner" of the mooc. We chose to present the work on the topic of the Letters of Paul, and on issues in teaching the Bible more generally, as a community project. HarvardX gave us the opportunity to showcase other scholars. We filmed conversations among the full teaching staff demonstrating the ways in which individuals can develop knowledge together in a seminar-setting. ${ }^{21}$ While the course did include short, mini-lectures by Nasrallah, these larger teaching staff conversations constituted the majority of film screen time, asking students to engage in longer-form videos modeling scholarly and reflective conversations. A filmed conversation with AnneMarie Luijendijk, of Princeton University, allowed us to show papyri from the Princeton collection and to learn from a scholar of early Christianity and papyrology. A discussion about teaching religion in the public schools highlighted the insights of Diane Moore, now head of the Religious Literacy Project at Harvard, alongside a former Harvard Divinity School student who teaches in a local high school. John Stendahl, a Lutheran pastor, discussed the life and work of his father, Krister Stendahl, a famous scholar of New Testament, bishop of Stockholm, Sweden, and former dean at Harvard; he also read one of his father's

20 Scholars from a variety of fields have reflected on feminist pedagogy and online education. On feminist pedagogy and moocs, see Callahan, Vicki, "Toward Networked Digital Scholarship: Mindful Media, Participatory Learning, and Distributed Authorship in the Digital Economy," Cinema Journal 53.1 (2013), 156-163; Chick, Nancy, Hassel, Holly, "Don't Hate Me Because I'm Virtual: Feminist Pedagogy in the Online Classroom," Feminist Teacher, Vol. 19, No. 3, 2009, 195-215. Even at the outset of online and distance education, feminist scholars have reflected on the pitfalls and promise of new technologies for women's studies and feminist pedagogy. See Whitehouse, Pamela, "Women's Studies Online: An Oxymoron?", Women's Studies Quarterly, Vol. 30, No. 3/4, 2002, 209-225; Cronan Rose, Ellen, “This Class Meets in Cyberspace': Women's Studies via Distance Education," Feminist Teacher, Vol. 9.2, 1995, 53-6o. For work in the area of democratic online education, see Lockard, Joseph, Pergum, Mark, "Brave New Classrooms: Democratic Education and the Internet", in: Peter Lang, Digital Formations 37, New York, NY, 2007. On conversations related to critical pedagogies and the digital humanities more broadly, see Losh, Elizabeth, Wernimont, Jacqueline, Wexler, Laura, Wu, Hong-An, "Putting the Human Back into the Digital Humanities: Feminism, Generosity, and Mess," Debates in the Digital Humanities, Gold, Matthew K., Klein, Lauren F., eds., Minneapolis, MN: University of Minnesota Press, 2016, 92-103. 
works to create a kind of podcast. ${ }^{22}$ Finally, with each launch of a "day" of work we included a section titled "Go Further/bibliography" in order to mark publicly that our MOOC participated in and depended upon broader scholarly conversations, just as our students' work online participated in a broader conversation. The students' conversations with each other, conversations with the teaching staff and other colleagues, and the bibliographies as indications of sources and scholarly conversations were demonstrations of a larger pedagogical point: myriad communities have wrestled through time to understand and to attribute meaning to ancient authoritative texts, and in doing so have not come to one firm meaning, but instead have shown the possibilities for rich, effervescent, and multiple meanings in these historical documents. The course's very organization was developed from the pedagogical foundation that learning happens best in collaboration, that multiple viewpoints show the complexity of a topic, and that each learner must take on the ethical responsibility of weighing his or her conclusions amid a range of scholarly options.

The course's explicit goals, stated on the syllabus and in an introductory short video, were, first, to investigate Paul's letters as a key record of struggle and debate over social, political, ethical, and theological issues; to learn about the Roman Empire, in which the Pauline correspondence was penned, and the second century world in which people wrote about or even as Paul. A second goal was for students to come to their own understanding of what the Pauline correspondence reveals about first century debate over several key issues. The final course objective was to engage ancient texts with disciplined intimacy. ${ }^{23}$

The course taught that this disciplined intimacy involves learning and practicing close reading. This close reading produces intimacy - the feeling that the text is speaking to the current reader, or that the situations it engages are similar to one's own. This form of close reading also requires the discipline or askessis of recognizing the cultural and temporal distance of the text, and of questioning whether the contemporary reader actually understands its terms at all. While students were not quizzed on particular pieces of information, such as the date of the book of Daniel, evidence for women's religious authority in antiquity, the definition of David Brakke's term "scriptural practices," ${ }^{24}$ or the socio-politics of the Roman colony of Corinth, the course asked them through several media to engage in and to practice certain reading strategies.

$22 \quad$ Letters of Paul Course Report, 19.

23 Letters of Paul Course Report, 5. See below for evidence related to learning outcomes (1727).

24 Brakke, David, "Scriptural Practices in Early Christianity: Toward a New History of the Canon," in: Ulrich, Jörg et al., eds., Invention, Rewriting, Usurpation: Discursive Fights for Religious Traditions in Antiquity, Frankfurt am Main: Peter Lang, 2012, 263-280. 
These strategies involved practicing how to read slowly and closely an ancient text, how to raise questions about its particularities, and how to avoid reducing one's questions to that of authorial intention, as if knowing what Paul really thought would fix the meaning of the text for those who received his letters in the first century CE or the generations who have received his letters since. ${ }^{25}$

To take a single example, on both the first and last day of the course, students were asked to respond to the Letter to Philemon. They were invited to annotate the text and respond to one another's annotations on the website Rap Genius, ${ }^{26}$ to discuss with one another what they thought were the circumstances that produced the letter, and to watch doctoral students engage with one another in a similar discussion. ${ }^{27}$ These assignments were designed to help students develop the academic practice of close reading strategies, to develop interpretations of ancient texts, and also, perhaps most significantly, to practice taking responsibility for their interpretations. ${ }^{28}$ Thus a simple assignment of annotation requires reflection on the content of an ancient texts, engagement with that content, but also reflection on the ethics of interpretation and the ethics of reading and responding to others' interpretations.

\section{Participation in Early Christianity: The Letters of Paul}

edX captures significant data about its student registrants; they capture not only demographics but everything "from mouse clicks to time spent on tasks."29 The teaching staff was not aware of this edX practice when the course began, nor that we could have engaged in a larger, meta-research process on learning processes and participation in the course. In the early days of HarvardX Moocs in 2013, data researchers at HarvardX created individual end-of-course reports, including one for HeroesX with Prof. Gregory Nagy and JusticeX with Prof. Michael Sandel; ${ }^{30}$ this research has since expanded to pedagogical and

25 See Johnson-DeBaufre, Melanie, Nasrallah, Laura, "Beyond the Heroic Paul: Toward a Feminist and Decolonizing Approach to the Letters of Paul," in: Stanley, Christopher, ed., The Colonized Apostle: Paul Through Postcolonial Eyes, Minneapolis: Fortress, 2011, 161-174; Marchal, Joseph, ed., The People beside Paul: The Philippian Assembly and History from Below, Atlanta: SBL Press, 2015; Nasrallah, Laura, Archaeology and the Letters of Paul, discusses these issues more fully.

26 The annotated text is still available: $<$ https://genius.com/2636137>, accessed on 10.04.19.

27 Letters of Paul Course Report, 43-44.

28 See a classic statement in Schüssler Fiorenza, Elisabeth, "The Ethics of Biblical Interpretation: Decentering Biblical Scholarship," JBL 107.1, 1988, 3-17.

$29<$ <ttps://www.edx.org/about/research-pedagogy>, accessed on 10.04.19.

30 <http://harvardx.harvard.edu/harvardx-working-papers $>$, accessed on 10.04.19. 
demographics research across multiple edX classes and, at Harvard, the development of the Research Committee for the Harvard University Vice Provost for Advances in Learning. ${ }^{31}$ At the time our course launched, HarvardX was no longer producing individual course reports. While we initially hoped to have the HarvardX research team help us create our own end of course report, instead we were given access to the raw data from the course, from which we created our own course report, which is available on the course website. ${ }^{32}$

Demographics data for all registrants for the course, as well as results from our end-of-course survey, completed by 2,748 course participants, allows us to gain some sense of whether and how our course met its learning goals. Our course had 32,036 enrollees as of March 2014 (see fig. 1). ${ }^{33}$ This is less than a tenth the size of some popular STEM courses; $\mathrm{CS}_{50 \mathrm{X}}$, a computer science course, enrolled 358,223 after launching in Spring of 2014. Our course issued 1,548 certificates ( $4.8 \%$ of course registrants), while HarvardX averaged a certification rate of $6 \% .^{34}$

In keeping with our pedagogical goals as stated above, our course fostered diverse conversation in several ways. Geographical and linguistic diversity characterized the students. Enrollees hailed from 169 countries, and a number of active users created discussion threads in Spanish, Portuguese, and Korean, among other languages. Some students even created Portuguese subtitled versions of the lecture, which they posted on youtube, to help fellow students. The conversation was also more age-diverse than other HarvardX Moocs. Our median student age was 35, while other HarvardX courses have a median age of 28 , with a majority of students aged 20-30. The number of registrants of the Early Christianity: The Letters of Paul for the age categories $71+$ represent more than $10 \%$ of total registrants in those age categories for all other HarvardX courses combined..$^{35}$ Many of these older students had never participated in

$31<$ http://harvardx.harvard.edu/research>, accessed on 10.04.19.

32 <https://div.hds.harvard.edu/lettersofpaul/course_report.pdf>, accessed on 10.04.19.

33 These numbers differ from those contained in the official course report, which captured data several months later, indicating that students continued to take the course beyond its "live" period. The Letters of Paul Course Report, $23 \mathrm{ff}$. All screen captures from edX websites are dated, because these sites continuously update with new statistics.

34 The certification rate varied widely from course to course, and also varied significantly over time, evidenced by a spike in registration and drop in certification following an appearance by an edX representative on Colbert, Stephen, et al., "HarvardX and MITx: The First Year of Open Online Courses, Fall 2012-Summer 2013," HarvardX and MITX Working Paper No.1, January 21, 2014) 13, accessible at <https://dspace.mit.edu/bitstream/handle/ 1721.1/96649/SSRN-id2381263.pdf?sequence=1>, accessed on 10.04.19.

Letters of Paul Course Report, 28. 

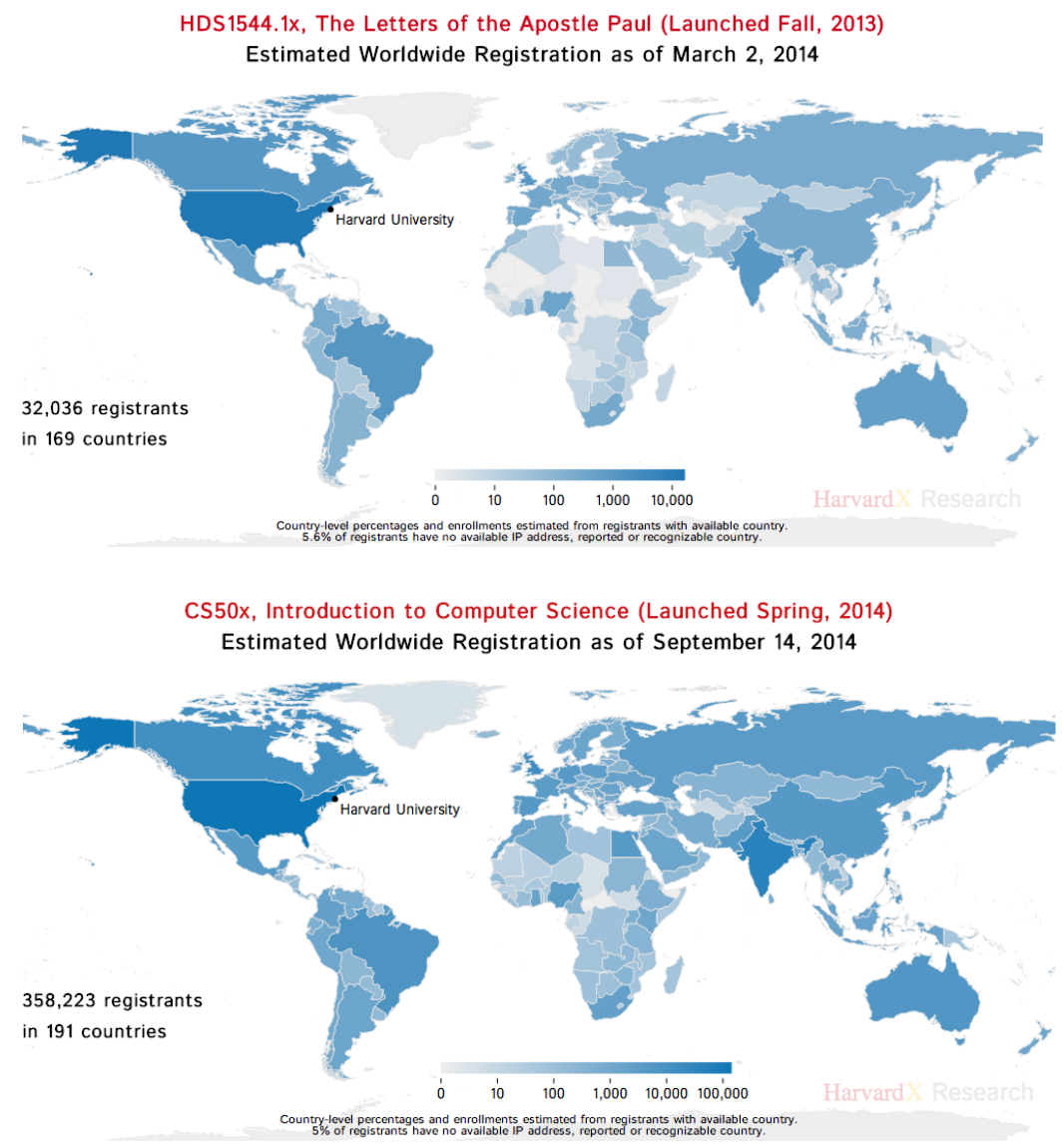

FIGURE 10.1 Registration of Early Christianity: The Letters of Paul as of March 2014 compared with registration of $\mathrm{CS}_{5} \mathrm{OX}$ as of September 2014.

Note: Letters of Paul Course Report, 23-24; @JENNIFER QUIGLEY AND

LAURA NASRALLAH, screen capture of HarvardX website, September 2014

an online course of any kind, and quite a few who mentioned their advanced age were some of our most enthusiastic voices in discussion threads.

The student-registrants for our course did not evidence the gender and educational diversity for which we had hoped. HarvardX M ooc enrollment on the whole is male-dominated; the average course is close to $60 \%$ male. ${ }^{36}$ Our course moved slightly more toward gender parity, at about $53 \%$ men. ${ }^{37}$ One

36 Nesterkos, Sergiy O., et al., "Gender Composition," HarvardX Insights, 2014. <http://har vardx.harvard.edu/harvardx-insights/gender-composition>, accessed on 10.04.19.

37 Letters of Paul Course Report, 25. 


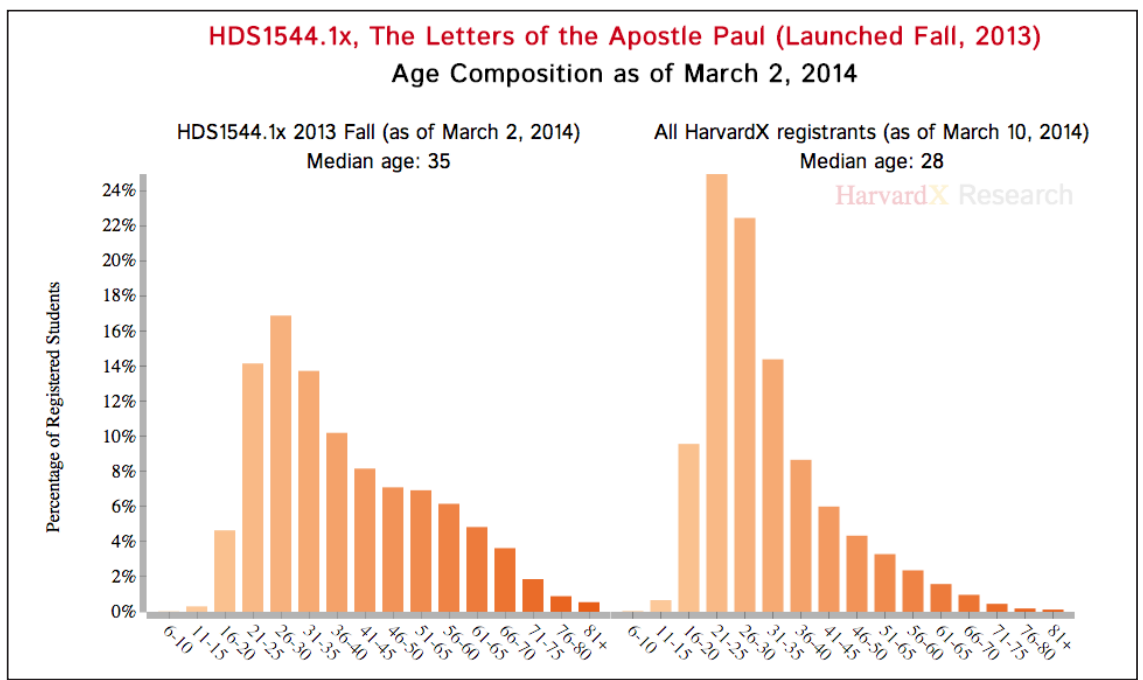

FIGURE 10.2 Early Christianity: The Letters of Paul, Age composition as of March 2014. Note: Letters of Paul Course Report, 28; @ JENNIFER QUIGLEY AND LAURA NASRALLAH, screen capture of HarvardX website, March 2014

other area where Moocs, including our course, fall short is in a striking education gap..$^{38} 72.7 \%$ of our students held undergraduate degrees, and $5.8 \%$ of our students hold doctoral degrees, while only $1.7 \%$ had less than a secondary level education. That is, three times as many Ph.D.s participated as persons without a high school degree or GED (United States educational terminology for General Education Development or high school equivalency degree). ${ }^{39}$

To return to our initial questions about feminist pedagogy and online education in our course, we have both positive and mixed results about whether and how our course formed a virtual space in which all could learn from each other. Early Christianity: The Letters of Paul created a truly global classroom and represented improvement in gender parity, in comparison with other HarvardX Moocs. The education gap of our course, however, was a sobering

38 Rohs, Matthias, Ganz, Mario, "Moocs and the Claim of Education for All: A Disillusion by Empirical Data" <http://www.irrodl.org/index.php/irrodl/article/view/2033/3527>, accessed on 10.04.19.

39 Letters of Paul Course Report, 26-27. This education gap varied depending on country of enrollment, ranging from $59.1 \%$ of South African enrollees to $88.9 \%$ of French enrollees holding a bachelor's degree or higher. Every country, however, had a significant majority of students who completed post-secondary education. This means that our course did not reach as broad or diverse of an audience as we would have liked; whether this had to do with our course offering or with the larger structures of edX/HarvardX is unclear. 


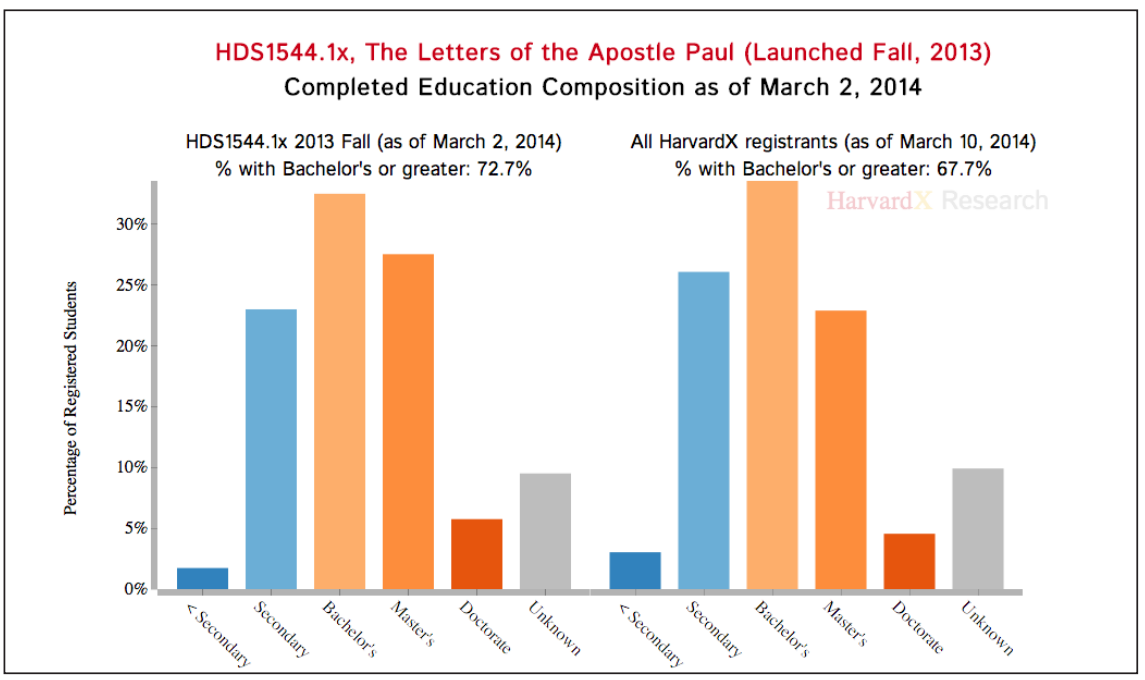

FIGURE 10.3 Early Christianity: The Letters of Paul, completed education composition as of March 2014; (CJENNIFER QUIGLEY AND LAURA NASRALLAH, screen capture of HarvardX website, March 2014

reminder that even when classes are free and online, that does not mean they are truly accessible to all learners.

\section{Outcomes from Early Christianity: The Letters of Paul}

The end of course survey proffered to students of our course was mainly formulated by edX according to the data that they wished to glean. We were able to add a few questions specific to our course concerns. 2,748 students took this end-of-course survey about their learning experience. Some of the questions on the survey asked students to respond about their learning. When asked how much students had learned in the course, $83 \%$ reported learning "a fair amount" or "a great deal." Only $4 \%$ of students reported learning little or nothing from the course. $66 \%$ of students said that the learning experience was "better" or "much better" than others they had had, $24 \%$ said that the experience was "about the same," and 10\% said the experience was "worse" or "much worse." 40

Students were asked to also rank the aspects of the course in which they perceived that they learned the most. ${ }^{41}$ Options included videos, readings, assessments, and discussions. A table of student responses follows, with a scale

$40 \quad$ Letters of Paul Course Report, 29.

41 This section excerpts from the Letters of Paul Course Report, 31-34. 
TABLE 10.2 End of course survey: Student learning and course components;

(C)JENNIFER QUIGLEY AND LAURA NASRALLAH, screen capture of HarvardX website, September 2014

\begin{tabular}{lllllll}
\hline Ranking & Answer & $\begin{array}{l}\mathbf{1} \\
\text { (learned } \\
\text { most) }\end{array}$ & & 3 & $\begin{array}{l}\text { 4 } \\
\text { (learned } \\
\text { least) }\end{array}$ & Total \\
& & & & & \\
\hline 1 & Videos & 995 & 307 & 58 & 34 & 1394 \\
2 & Readings & 327 & 899 & 132 & 36 & 1394 \\
3 & Assessments & 22 & 56 & 703 & 613 & 1394 \\
4 & Discussion & 50 & 132 & 501 & 711 & 1394 \\
Total & Forums & & & & & \\
\hline
\end{tabular}

of 1 (perceived learning the most from this portion of the course) to 4 (perceived learning the least from this portion of the course) (Table 10.2).

Qualitatively, students were also asked open-response questions, including one soliciting what were the most intellectually transformative parts of the course. Both the quantitative and qualitative responses aligned well with the stated learning goals of the course, and students largely responded that learning about the historical, political, and literary context of the letters of Paul were the most intellectually transforming, often citing specific lessons, concepts, and course content. Not atypically, one student wrote:

The lessons about historical, social and religious context were transforming. Learning about letter writing helped me to understand the purpose of the prescript and letter format, which had always confused me. Finally and perhaps most importantly lesson 11 on wisdom, knowledge and prophecy has given me insights that are still developing and may still develop for some time to come, for me.

Other students also reported being transformed by the aspects of the course that focused on material culture in antiquity; again, many mentioned specific sites, images, and concepts. Some students were even inspired to do additional research outside of the bounds of the course. One student wrote:

Household Management discussion / Aristotle. Considering the veiled women section in Corinthians. Walking out here to read L. Nasrallah's article on Thessalonike and understanding the apse mosaics. (Empire and Apocalypse). Great article! 
There were frequent positive responses to the lecture videos, doctoral student discussion videos, and the videos with Prof. AnneMarie Luijendijk and Rev. John Stendahl. One student wrote:

I loved John Stendahl's reading of Krister Stendahl's lecture on "Why I Love the Bible." That lecture left me thinking and talking about the topics he raised for a couple of weeks and I could probably talk about it today too!

Many students reported being most transformed by interactions and conversation with fellow students. Students found interactions with one another to be both challenging and intellectually productive. One typical response follows:

I was transformed by the discussions being so civil that it made my real life discussion also very civil and fruitful.

Lastly, many students reflected on their learning about taking responsibility for their interpretations, and quite a few reported feeling better equipped to read the Bible. Two particularly reflective responses follow:

\section{Response 1}

As an atheist enrolling in a course offered through a divinity school, I was understandably nervous about what I was getting myself into. Perhaps I shouldn't have been so surprised to see that the materials were presented in such a scholarly way. I expected to be told what Paul's letters meant from a theological standpoint; instead I learned how to read Paul's letters. Having an understanding the social/cultural/historical context is crucial for reading these ancient texts and now I have the tools to decipher them on my own.

\section{Response 2}

This course has helped me to do something different: to look at the texts themselves and notice the subtleties of language and vocabulary, read what I can of the history and social setting, and trust that these all of these things matter.

Going forward, the experience of this course encourages me to do a couple of things:

Read more slowly. I read and/or hear these texts all the time. I read one verse knowing the verse that comes next, which is to say that I am not paying close attention anymore. To do the work in this course, I had to read slowly and with a beginner's ear. 
Read the whole letter more often. The lectionary snippets are fine, but they are read out of context. Context matters: literary, social and political. Take guesses. All anyone has is the nutmeg grater: ${ }^{42}$ everyone is guessing. Some guesses are better informed than others, BUT some guesses that now pass as certain knowledge were not good guesses at all. Junia ${ }^{43}$ will always remind me of that.

Check the data. More than once in this course I presumed my response to the Discussion Question would go in one direction, only to find that the data I could gather did not point in that direction at all.

Pay attention to what I feel when I read. I was taught to do that in my first scripture courses, but one forgets and gets busy and opens the commentary too soon.

Finally, there are those wonderful Bibliographies at the end of each Day's lesson. I originally planned to audit this course - just listen in - in the hopes that I would be able to figure out what folks are saying about Paul today, in 2014. By Day 1 or 2 I had changed my mind and decided to do the work. What a good decision. Seldom does it happen that the rewards are commensurate with the work, but that was the case in this course. I attribute that to careful planning in the course design. Bravo course designers! By the time we were mid-way through, I knew that if I put the time and effort in to the exercise, I would learn something. In fact, I learned a lot. AND I have these wonderful bibliographies to explore.

Turning to the question of whether and how our MOOC was able to create a pedagogical space in which students and teachers understood themselves as co-learners and producers of knowledge, the data reveals a remarkable level of connection and engagement for an online setting. $80 \%$ of respondents to our end-of-course survey (which included 2,748 of our more active participants) reported feeling somewhat, very, or extremely connected to the community of learners and instructors for the course, while $85 \%$ felt that the teaching team was somewhat, very, or extremely accessible. ${ }^{44}$

42 The Day 2 lecture quoted Carolyn Steedman on archives, saying, "Your craft is to conjure a social system from a nutmeg grater." Steedman, Carolyn, "Something She Called a Fever: Michelet, Derrida, and Dust," The American Historical Review 106, no. 4, October 2001, 1165. Here the student refers to the lecture and discussion in our course about Rom 16:7. The phrase "Junia, remarkable among the apostles," which in Greek is clearly a female personal name, was emended in various manuscripts and translations to Junias, a male name. See Brooten, Bernadette, "Junia ... Outstanding among the Apostles," in: Swidler, Leonard and Arlene, eds., Women Priests: A Catholic Commentary on the Vatican Declaration, New York: Paulist, 1977, 141-144.

Letters of Paul Course Report, 29. 
The students also produced their own subcommunities during the course. As mentioned before, language-specific groups formed themselves; for example, a Spanish-language group emerged on Facebook and one student translated the lectures into Portuguese. Community-building was not just virtual: students reported having in-person meetings with other students in the course. Moreover, students extended the community of learners: $40 \%$ of respondents completed the course or used some of its materials in face-to-face meetings with others. ${ }^{45}$ From informal conversations with friends and family, to formal local meet-ups, to church and other faith community groups taking the course together, a significant number of students embodied the collaborative value of the teaching team by finding in-person communities with which to learn. Students who met face-to-face were asked to describe this experience. Two of these responses follow:

\section{Response 1}

There were so many in the class, so many ideas and points of views. We had a local group of ten who took the class and are still meeting to discuss the readings. I would have like to be placed in a group of ten from around the world. I think it would have been useful for me to have a specific group to respond to.

\section{Response 2}

I talked my church Bible study group into doing it, so we'd meet once per week for further discussion. ${ }^{46}$

In addition, some "super-users" of the various course venues, particularly the discussion thread, regularly engaged with one another, and even reached out to one another at the end of the course. We had quite a few closing comments that thanked not only teaching staff members, but also fellow students by name. One example follows:

As lessons went by I found myself doing more research in internet on the subject then I would have expected at the beginning and in the end a new knowledge came to me and made me appreciate more and more the assignments and the discussion treads, even if I don't know why by the time I finished reading my assignments, all where full of posts and comments and I mostly restricted myself to comments on somebody also posts. How

\footnotetext{
45 Letters of Paul Course Report, 30.
}

46 Letters of Paul Course Report, 30. 
did they do it I don't know but my compliments to $\mathrm{l}^{* * * * * * *}-\mathrm{A}^{* * * * * * * * *}$ $-\mathrm{A}^{* * * * * * * * * * * *}$ and all others who supplied me with a lot of information. [sic]

On the whole, the teaching team was pleasantly surprised by the civility and deep engagement of these conversations. For example, on our discussion boards, an atheist and a born-again Christian disagreed respectfully (Fig. 10.4).

In other cases, students gently corrected one another and pushed each another to think more critically (Fig. 10.5).

Students thus practiced the goals of the course. As the course was concluding they also in their own words reflected some of the goals of the course. On February 17, 2014, one student posted on Facebook:

Excellent video - my favorite quote is "In Paul's letters, theological language and ... thought is a response to historical realities." Perhaps more than anything, this course has shown me that historians, no matter where they are coming from, still carry bias, and Paul's letters, like all of the Bible, must be understood (especially by people of faith), in their historical context, not just with the eyes of faith. Our bias does get in the way! Whether by omission of "small details" or facts, or history, or by myopia with issues of the time, our viewpoints can hinder an accurate (or more accurate) understanding of the truth.

This post gave Nasrallah the opportunity to expand, articulating a feminist hermeneutics:

Thank you so much, - - And I want to expand a bit on what you said. Our biases can hinder, and they can also expand the range of questions that we can ask about the historical context (and theological potentials) of Paul's letters - that is, our standpoints both limit us and help us to see from new angles. That is one reason that studying in community, where others can push, correct, and learn from us, is so great! (posted February 23, 2014).

Some students articulated the feminist pedagogical claim that they were cocreators of learning in the course. On February 5, 2014, as the course was coming to a close, one student offered a post: "Thank you very much for the knowledge and experience gained through this course! Maybe there should be a sequel in the future, a part B perhaps!!!" Another responded to her post, 


User P
2 months ago
I have to start this by stating that I am a very strong atheist with a rather negative view of Paul,
but I wanted to take this course in order to learn more about him. In my first proper study of his
prescripts, my view of Paul has become even more negative. I understand the need for the
from and to aspects of letter writing, but his continual pointing out of his "apostleship" and "his
calling by God" is no different that Vernon Wayne Howell changing his name to David Koresh.
By changing his name to David Koresh, he was calling himself the spiritual descendant of King
David and a messiah involved in the work of God. How is Paul any different? He didn't have the
ability to change his name to something as meaningful as David Koresh, but he could
continually point out his so-called commission by God, which is what he did.
Sorry, I'm not trying to ruffle anyone's feathers here, but I'm supposed to respond somehow
and I'd rather be honest about what I see and feel.
$\quad>$ Edit

I think the difference between Paul and David Koresh is that Paul was humble and recognized that he was nothing without God, while David Koresh manipulated people and eventually his actions led to their deaths.

-posted 2 months ago by User T

I am born again. You have not ruffled my feathers. I think Paul makes such titles of himself for the benefit of the group to whom he writes. The titles I think made it easier for the ekklesai to relate to the message they were receiving. As for his name, and appointment they were given to him by God himself. He used the name in the commission of that appointment which was to spread the Gospel. I can't say about David Koresh, he wrote nothing I am remotely familiar with and if he did write something I most likely would not have wasted my time reading it.

-posted 2 months ago by User B

@UserT Very nice clarity

-posted 2 months ago by User B

I think Paul could appear humble when it suited him, but he wasn't really humble, particularly when he was angry. He spoke of himself as superior to other apostles; he called himself a father of the people when Jesus clearly said there is no father but one. Paul's teachings were of Paul, not those of Jesus. We only have his word of his appointment by God and he always seemed to use that as self-promotion, which is not humble at all.

-posted 2 months ago by User P

I think you bring up a couple of interesting points. However, I think we also need to understand that these letters are only a very small glimpse into Paul's life. I don't know if he is humble or not (and as a disclaimer, I am a Christian who tends to put Paul on the arrogant side of things), because we only have the letters. Additionally, we have to be careful not to read our own cultural interpretation of greetings into a $1^{\text {st }}$ century Roman world. If there were common practices, especially in letter writing, then they likely were not intended or perceived as prideful or arrogant.

I think your claim that he used this for self promotion is interesting. I don't know if I'd compare it to David Koresh, honestly, but what evidence makes you think it was used in this way? I am curious as to why you think this because Paul is one of those people, especially when taken up in our own society, that tends to irk some (again, myself sometimes included). -posted 2 months ago by User A
FIGURE 10.4

Sample student

discussion 1;

(C)JENNIFER

\section{QUIGLEY AND}

\section{LAURA}

NASRALLAH, screen capture of HarvardX website, September 2014 


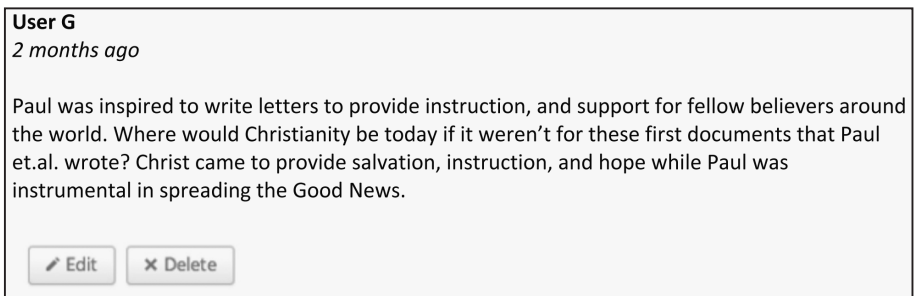

\begin{tabular}{|c|c|}
\hline $\begin{array}{l}\text { Interesting counterfactual questi } \\
\text { requires a complex counterfactua } \\
\text { interest those that into causality. } \\
\text { the impact of Paul's letters?" The } \\
\text { have gone into the New Testame }\end{array}$ & $\begin{array}{l}\text { a question } \\
\text { hg that } \\
\text { Jhat was } \\
\text { else might } \\
\text { lation. }\end{array}$ \\
\hline -posted 2 months ago by User C & $\times \times$ \\
\hline $\begin{array}{l}\text { If Paul is right and Jesus is the Chr } \\
\text { these letters would not make it to } \\
\text { hypothetically/academically what } \\
\text { the other books of the New Testa }\end{array}$ & $\begin{array}{l}\text { ibility that } \\
\text { e still had } \\
\text { d still exist. }\end{array}$ \\
\hline -posted 2 months ago by User M & $\nabla \times 1=$ \\
\hline $\begin{array}{l}\text { In regard to User M's comment, a } \\
\text { and preservation of these letters? } \\
\text { chance. There are many manuscr } \\
\text { reasons having nothing to do with }\end{array}$ & $\begin{array}{l}\text { nsmission } \\
\text { nt do so by } \\
\text { es for }\end{array}$ \\
\hline -posted 2 months ago by User E & $\times 10$ \\
\hline $\begin{array}{l}\text { Who would think that a persecutc } \\
\text { preacher of the Gospel of Jesus } \\
\text { apostles and followers would thin } \\
\text { Paul has really fulfilled his mission } \\
\text { the Gospel. }\end{array}$ & $\begin{array}{l}\text { ne the } \\
\text { that the } \\
\text { o proclaim }\end{array}$ \\
\hline -posted 2 months ago by User $\mathbf{N}$ & $\times 10$ \\
\hline $\begin{array}{l}\text { I agree with User E's comments. } \\
\text { as to which gospels, probably lett } \\
\text { as part of the canon. Even today, } \\
\text { sets of books (see http://catholic- }\end{array}$ & $\begin{array}{l}\text { ly church } \\
\text { e included } \\
\text { ifferent }\end{array}$ \\
\hline -posted 2 months ago by & $\times 10$ \\
\hline
\end{tabular}

FIGURE 10.5

Sample student discussion 2; (C) JENNIFER QUIGLEY AND

\section{LAURA}

NASRALLAH, screen capture of HarvardX website, September 2014

saying: "We are the sequel ... it's one thing studying and gaining knowledge but another to put it into practice. We are now in the fortunate position of being equipped to create our own 'Letters of Paul' II."

As the teaching staff worked on the production of edX's Early Christianity: The Letters of Paul, we also engaged in a mini-seminar with readings that al- 
lowed us to consider broader issues in the industry of education. ${ }^{47} \mathrm{~A}$ central conversation point of our mini-seminar was that many of us on the teaching staff were drawn to higher education because in the university we find a quasi-utopian space (as perhaps also in religious communities and activist communities) to think about the world differently: to experiment with means of liberation and with productive struggle, to learn lessons for transformation to take out and apply in broader contexts, as well as to further the work of disciplined attention to materials from antiquity.

As problematic as online education can be for as universities and for-profit ventures seek to monetize online learning, the MOос also gave us some hope about transformative thinking and practices happening in the online teaching environment. The MOOC in particular and online education in general need not be primarily a concession to the expense and challenge of bringing students into one place. It can be a way to accommodate a hunger for knowledge, the longing for continuing education and broad communication and community. Ashon Crawley's Blackpentecostal Breath touches upon the topic of transforming the academy, focusing on "blackpentecostal aesthetic practice." This practice "ruins' the normative, neoliberal university, 'ruins' such a zone of inhabitation in the service of producing otherwise possibilities," writes Crawley. ${ }^{48}$ It is these otherwise possibilities that interest Crawley, the overflow of glossolalia, the university as "a great gathering of resources that should, it should be said, be exploited and put in the service of the search into the dark, dense folks of nothingness, the dark, dense folds of plentitude."49 A Mоoc, particularly one with feminist pedagogical frameworks and inspired by the theorizing of education and pedagogy by scholars like hooks and Crawley, has the potential for this effervescent glossolalic transformation of the university, drawing in a

$47 \quad$ Although the seminar's readings were largely focused on debates about Moocs in 20132014, as well as feminist pedagogy and discussions about pedagogy in biblical studies, a broader seminar might include Veblen, Thorsten, The Higher Learning in America: A Memorandum on the Conduct of Universities by Business Men (1918), Baltimore: Johns Hopkins University Press, 2015. Veblen seems prescient in his concerns about the organizational scheme of universities and his analysis of and concerns about "this incursion of business principles into the affairs of learning" (217). For a critique of neoliberalism in the university, see Brown, Wendy, Undoing the Demos: Neoliberalism's Stealth Revolution, New York: Zone Books, 2015, chapter 6: “Educating Human Capital." For our mini-seminar syllabus, see Appendix A, Letters of Paul Course Report, <https://div.hds.harvard.edu/let tersofpaul/course_report.pdf>, accessed on 10.04.19.

48 Crawley, Ashon, Blackpentecostal Breath: An Aesthetics of Possibility, New York: Fordham University Press, 2016, 250.

49 Crawley, Ashon, 2016, 237. See also Harney, Stefano, Moten, Fred, The Undercommons: Fugitive Planning and Black Study, chapter 2: "The University and the Undercommons," Wivenhoe: Minor Compositions, 2013, 22-43. 
diversity of voices, and spilling over the bounds of brick and mortar and into the larger world.

\section{References}

Anand, Bharat, The Content Trap: A Strategist's Guide to Digital Change, New York: Random House, 2016, 299-344.

Barber, Michael, Donnelly, Katelyn, Rizvi, Saad, "An Avalanche is Coming: Higher Education and the revolution ahead", London: Institute for Public Policy Research, 2013, $<$ http://www.avalancheiscoming.com/>, accessed on 10.04.19.

Brakke, David, "Scriptural Practices in Early Christianity: Toward a New History of the Canon," in: Ulrich, Jörg et al., eds., Invention, Rewriting, Usurpation:Discursive Fights for Religious Traditions in Antiquity, Frankfurt am Main: Peter Lang, 2012, 263-280.

Brooten, Bernadette, “'Junia ... Outstanding among the Apostles," in: Swidler, Leonard and Arlene, eds., Women Priests: A Catholic Commentary on the Vatican Declaration, New York: Paulist, 1977, 141-144.

Brown, Wendy, Undoing the Demos: Neoliberalism's Stealth Revolution, New York: Zone Books, 2015, chapter 6: "Educating Human Capital." For our mini-seminar syllabus, see Appendix A, Letters of Paul Course Report.

Callahan, Vicki, "Toward Networked Digital Scholarship: Mindful Media, Participatory Learning, and Distributed Authorship in the Digital Economy," Cinema Journal 53.1, (2013) 156-163.

Chick, Nancy, Hassel, Holly, "Don't Hate Me Because I'm Virtual: Feminist Pedagogy in the Online Classroom," Feminist Teacher, Vol. 19, No. 3, 2009, 195-215.

Colbert, Stephen, et al., "HarvardX and MITx: The First Year of Open Online Courses, Fall 2012-Summer 2013," HarvardX and M IT x Working Paper No.1, January 21, 2014, 13, accessible at $<$ http://dspace.mit.edu/bitstream/handle/1721.1/96649/SSRN-id2381 263.pdf?sequence $=1>$; accessed on 10.04.19.

Crawley, Ashon, Blackpentecostal Breath: An Aesthetics of Possibility, New York: Fordham University Press, 2016, 250.

Cronan Rose, Ellen, “'This Class Meets in Cyberspace': Women's Studies via Distance Education," Feminist Teacher, Vol. 9.2, 1995, 53-6o.

Harney, Stefano, Moten, Fred, The Undercommons: Fugitive Planning and Black Study, chapter 2: "The University and the Undercommons," Wivenhoe: Minor Compositions, 2013, 22-43.

hooks, bell, Teaching to Transgress: Education as the Practice of Freedom, New York: Routledge, 1994.

Johnson-Debaufre, Melanie, Nasrallah, Laura, "Beyond the Heroic Paul:Toward a Feminist and Decolonizing Approach to the Letters of Paul," in: Stanley, Christopher, ed., 
The Colonized Apostle: Paul Through Postcolonial Eyes, Minneapolis: Fortress, 2011, 161-174.

Lockard, Joseph, Pergum, Mark, "Brave New Classrooms: Democratic Education and the Internet”, in: Digital Formations 37, New York: Peter Lang, NY, 2007.

Losh, Elizabeth, Wernimont, Jacqueline, Wexler, Laura, Wu, Hong-An, "Putting the Human Back into the Digital Humanities: Feminism, Generosity, and Mess," Debates in the Digital Humanities, Gold, Matthew K., Klein, Lauren F., eds., Minneapolis, MN: University of Minnesota Press, 2016, 92-103.

Marchal, Joseph, "To What Ends? Biblical Studies and Critical Rhetorical Engagement(s) for a 'Safer' World," sBL Forum n.p. Online: <http://sbl-site.org/Article.aspx?Arti cleID $=550>$, accessed on 10.04.19.

Marchal, Joseph, The People beside Paul: The Philippian Assembly and History from Below, Atlanta: SB L Press, 2015.

Martin, Dale, Pedagogy of the Bible: An Analysis and Proposal, Louisville, KY: Westminster John Knox, 2008.

Nasrallah, Laura, Archaeology and the Letters of Paul, Oxford: Oxford University Press, 2018.

Nesterkos, Sergiy O., et al., "Gender Composition," HarvardX Insights, 2014, <http://har vardx.harvard.edu/harvardx-insights/gender-composition>, accessed March 2014.

Rohs, Matthias, Ganz, Mario, "Moocs and the Claim of Education for All: A Disillusion by Empirical Data”, <http://www.irrodl.org/index.php/irrodl/article/view/2 033/3527>, accessed on 10.04.19.

Schüssler Fiorenza, Elisabeth, Democratizing Biblical Studies: Toward an Emancipatory Educational Space, Louisville, KY: Westminster John Knox, 2009.

Schüssler Fiorenza, Elisabeth, "The Ethics of Biblical Interpretation: Decentering Biblical Scholarship," JBL 107.1, 1988, 3-17.

Steedman, Carolyn, "Something She Called a Fever: Michelet, Derrida, and Dust," The American Historical Review 106, no. 4, October 2001, 1165.

Veblen, Thorsten, The Higher Learning in America: A Memorandum on the Conduct of Universities by Business Men (1918), Baltimore: Johns Hopkins University Press, 2015. Whitehouse, Pamela, “Women's Studies Online: An Oxymoron?", Women's Studies Quarterly 30, No. 3/4, 2002, 209-222.

\section{List of Internet Resources}

$<$ http://www.thegreatcourses.com/>, accessed on 10.04.19.

$<$ https://www.edx.org/course/jesus-scripture-tradition-notredamex-th120-1x>, accessed on 10.04.19.

<https://www.coursera.org/learn/the-talmud>, accessed on 10.04.19. 
<https://www.edx.org/xseries/world-religions-through-scriptures >, accessed on 10.04.19.

$<$ https://www.bibleodyssey.org/>, accessed on 10.04.19.

$<$ http://archive.boston.com/bostonglobe/ideas/brainiac/2013/05/san_jose_state. html $>$, accessed on 10.04.19.

<http://www.chronicle.com/article/The-Document-an-Open-Letter/138937>, accessed on 10.04.19.

$<$ http://www.chronicle.com/article/Michael-Sandel-Responds/139021/>, accessed on 10.04.19.

$<$ http://www.justiceharvard.org/>, accessed on 10.04.19.

$<$ https://www.edx.org/course/early-christianity-letters-paul-harvardx-hds1544-1x.>, accessed on 10.04.19.

$<$ http://div.hds.harvard.edu/lettersofpaul/>, accessed on 10.04.19.

$<$ http://www.thechristians.com $>$, accessed on 10.04.19.

$<$ http://femtechnet.newschool.edu/docc2013>, accessed on 10.04.19.

$<$ https://genius.com/2636137>, accessed on 10.04.19.

<https://www.edx.org/about/research-pedagogy>, accessed on 10.04.19.

<http://harvardx.harvard.edu/harvardx-working-papers >, accessed on 10.04.19.

$<$ http://harvardx.harvard.edu/research $>$, accessed on 10.04.19.

$<$ https://div.hds.harvard.edu/lettersofpaul/course_report.pdf >, accessed on 10.04.19. 